the acceptance of finite strain and the inclusion of self-weight.

The extension of any model to an environment different from that in which it has been tested should be undertaken with great care. In this case, a simple model has provided good correlation with accurate laboratory measurements, but an extension to field conditions is likely to require greater flexibility with regard to the soil parameters. This could be achieved with either approach.

\section{REFERENCE}

Gibson, R. E., England, G. L. \& Hussey, M. J. L. (1967). The theory of one-dimensional consolidation of saturated clays. I. Finite non-linear consolidation of thin homogeneous layers. Géotechnique 17, No. 3, 261-273.

\title{
In situ measurement of horizontal stress in overconsolidated clay using push-in spade-shaped pressure cells
}

\section{P. TEDD and J. A. CHARLES (1981). Géotechnique 31, No. 4, 554-558}

Professor J. B. Burland and $\mathrm{Mr} \mathrm{J}$. Maswoswe, Imperial College of Science and Technology

The Authors present in situ measurements of horizontal stress at a site in Essex made using push-in pressure cells and the Camkometer. We have been engaged in a laboratory study of the soil properties at this site. In particular, careful measurements of the capillary pressure $p_{\mathbf{k}}{ }^{\prime}$ have becn made which can be used to detcrminc the horizontal stress using the method suggested by Skempton (1961).

The samples were $105 \mathrm{~mm}$ in diameter and $600 \mathrm{~mm}$ long and were obtained by thin-walled push sampling. They were stored in the steel tubes with waxed ends. Each sample was trimmed to $102 \mathrm{~mm}$ in diameter and $204 \mathrm{~mm}$ in height. Pore pressure was measured using a high air entry porous disc and a transducer. Contact between sample and porous disc should be avoided during setting up and this was achieved by standing the sample on two semi-circles of fuse wire $(0.864 \mathrm{~mm}$ in diameter). The small amount of air trapped by this procedure would be dissolved under the high cell pressures that were used. During the setting up period the pore pressure in the measuring system was monitored and no significant drop in pressure was observed. Filter paper drains were not used as it has been found that these substantially affect initial sample suction.

After mounting and jacketing the sample the cell was rapidly filled with water and a cell pressure of $800 \mathrm{kN} / \mathrm{m}^{2}$ applied. On application of the cell pressure the fuse wire was forced into the sample base and the sample came into contact with the porous disc and the pore pressure measuring system. The sample was then left for about two days so that any pore pressure gradients within the sample could equalize. A small increment of cell pressure was then applied in order to check the value of the pore pressure parameter $B$. The difference between the measured pore pressure and the applied cell pressure was taken as the initial suction $p_{\mathrm{k}}{ }^{\prime}$ of the sample.

The results of four tests from the Essex site are given in Table 1 . The values of $K_{0}$ have been derived from the expression

$$
K_{0}=\frac{p_{\mathrm{k}}{ }^{\prime} / \sigma_{\mathrm{v}}{ }^{\prime}-A_{\mathrm{s}}}{1-A_{\mathrm{s}}}
$$

where $A_{\mathrm{s}}$ has becn taken as $\frac{1}{3}$ and $\frac{1}{2}$. A value of

Table 1. Measured values of capillary pressure $p_{k}{ }^{\prime}$ and associated values of $K_{0}$ and $\sigma_{\mathrm{H}}$

\begin{tabular}{c|c|c|c|c|c|c|c|c|c}
\hline $\begin{array}{c}\text { Depth: } \\
\mathrm{m}\end{array}$ & $\begin{array}{c}\text { Soil } \\
\text { type* }\end{array}$ & $\begin{array}{c}\text { Overburden } \\
\text { pressure } \sigma_{*}: \\
\mathrm{kN} / \mathrm{m}^{2}\end{array}$ & $\begin{array}{c}\text { Pore } \\
\text { pressure } u \\
\mathrm{kN} / \mathrm{m}^{2}\end{array}$ & $\begin{array}{c}p_{\mathrm{k}}^{\prime}: \\
\mathrm{kN} / \mathrm{m}^{2}\end{array}$ & \multicolumn{2}{|c|}{$B$} & \multicolumn{2}{|c|}{$A=\frac{1}{3}$} & \multicolumn{2}{|c|}{$A=\frac{1}{2}$} \\
\hline 3 & $\mathrm{CB}$ & 60 & 0 & 65 & 0.972 & 1.12 & 67 & $1 \cdot 16$ & 69 \\
$8 \cdot 4$ & $\mathrm{LC}$ & 168 & 52 & 155 & 0.975 & 1.51 & 227 & 1.68 & 247 \\
$15 \cdot 1$ & $\mathrm{LC}$ & 302 & 117 & 231 & 0.991 & 1.35 & 370 & 1.47 & 391 \\
$19 \cdot 7$ & $\mathrm{LC}$ & 394 & 162 & 347 & 0.971 & 1.75 & 567 & 1.99 & 624 \\
\hline
\end{tabular}

* CB Claygatc beds, LC London clay. 


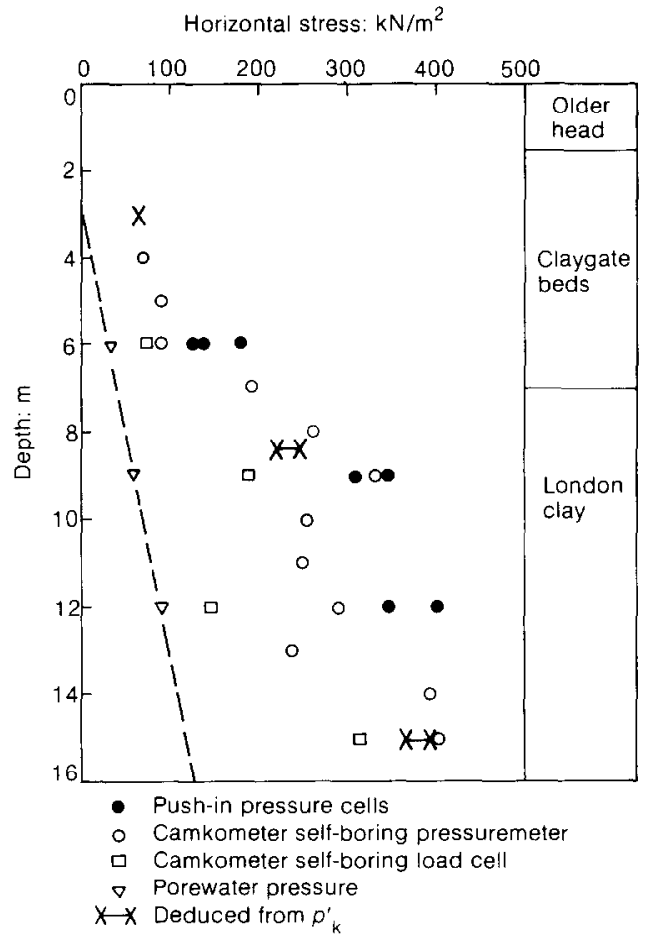

Fig. 1

$A_{\mathrm{s}}=\frac{1}{3}$ corresponds to an isotropic elastic material; London clay typically gives initial values of $A_{\mathrm{s}}$ of approximately $\frac{1}{2}$.

In Fig. I the laboratory determined values of total horizontal stress $\sigma_{\mathrm{H}}$ are compared with the measurements presented by the Authors using push-in pressure cells and the Camkometer. The laboratory determinations lie within the scatter of the Camkometer self-boring pressuremeter results and hence a little below the measurements made with the push-in pressure cells.

The results of the laboratory investigation give support to the validity of the field measurements of horizontal stress that have been made at the Essex site. The laboratory measurements of $p_{\mathrm{k}}{ }^{\prime}$ may be on the high side because of suctions set up by local shearing between the walls of the sample tube and the soil during the sampling operation. A correction for this would bring the laboratory values of $\sigma_{\mathrm{H}}$ closer to the Camkometer self-boring load cell results.

The work described forms part of a programme of research funded by the Transport and Road Research Laboratory, Department of Transport, and the results are published by permission of the Director.

\section{REFERENCE}

Skempton, A. W. (1961). Horizontal stresses in an overconsolidated Cocene clay. Proc. 5th Int. Conf. Soil Mech., Paris 1, 351-357.

\section{Authors' reply}

Professor Burland and $\mathrm{Mr}$ Maswoswe have presented useful information from their laboratory study of capillary pressure in undisturbed samples from the Essex site. Their data complement the in situ measurements of horizontal stress from pushin pressure cells and the Camkometer. The laboratory determinations of total horizontal stress are greater than the Camkometer self-boring load cell results. They lie within the scatter of the self-boring pressuremeter results and are a little below the measurements made with the push-in pressure cells. The push-in cells could be expected to over-read slightly due to the method of installation.

In attempting evaluation of these different methods of measuring horizontal stress, the principal difficulty is the lack of knowledge of the actual horizontal pressure in the undisturbed clay. This absence of knowledge is not peculiar to the Essex site but is always the case. However, the vertical stress at shallow depths in uniform soil conditions below a level ground surface is known with reasonable certainty and is equal to the overburden pressure. There has recently been an opportunity to install push-in spade-shaped pressure cells from a tunnel bored in the London clay. Cells have been installed to measure vertical stress and it is hoped that a comparison with known overburden pressure will lead to a better understanding of the amount push-in cells overread in London clay. 